\title{
Conditions for Ensuring Energy-Saving Use of Translucent Structures of Exterior Wall Envelope
}

\author{
Vitalii Burmaka ${ }^{a}{ }^{*}$, Mykola Tarasenko $^{a},{\text { Kateryna } \operatorname{Kozak}^{a} \text {, Nataliia Sabat }}^{b}$, \\ Viktor Khomyshyn ${ }^{a}$, Volodymyr Yuskiv ${ }^{a}$ \\ ${ }^{a}$ Ternopil Ivan Puluj National Technical University, Ternopil, 46001, Ukraine \\ ${ }^{b}$ Ivano-Frankivsk National Technical University of Oil and Gas, Ivano-Frankivsk, 76019, Ukraine
}

Received: August 28, 2020. Revised: October 12, 2020. Accepted: October 19, 2020.

(C) 2020 The Authors. Published by Lviv Polytechnic National University.

\begin{abstract}
The article focuses on determining the translucent structures of exterior wall envelope (TSEWE) properties influence on the total energy balance of the room. The dependence of the energy consumption for artificial lighting on the daylight factor, coefficient of relative penetration of solar radiation (CRPSR) and TSEWE area is determined for Ternopil city. The relationship between the electricity expenses for heating and cooling the room by channel air conditioners on the size and properties of TSEWE is established. Inequalities were obtained that allow us to establish the conditions under which the TSEWE use will have a positive effect on the total energy balance of the office room for the Ternopil city. According to the obtained results, it is possible to determine the thermal resistance, CRPSR and the TSEWE area at which energy savings will occur while observing the climate conditions in the room prescribed by regulations documents.
\end{abstract}

Keywords: TSEWE; daylight factor; composite index of glazing rooms; energy efficiency of daylighting.

\section{Introduction}

Using sunlight to illuminate rooms is one of the obvious ways to save energy. Humans are biologically adapted to daylight. Its optimal use can significantly reduce the electricity expenses for artificial lighting. To do this, it is necessary to choose the right size, thermal and lighting characteristics of the translucent structures of exterior wall envelope (TSEWE).

At present, the main attention when solving the issue of lighting the rooms is focused on the use of artificial light sources, which, according to the International Energy Agency, consume about 19\% of the total world energy consumption [1]. Electric lighting still dominates the field of light space. Effective standards for daylighting of rooms are only in European countries (DIN EN 12464-1:2011-08).

That is why leading experts of the developed countries of the world consider the issue of the proper organization of daylighting of various kinds of rooms to be especially relevant. The use of only one type of lighting in most cases is not only irrational, but also does not meet the needs of a person in maintaining his health. So, the complete absence of daylight, by labor protection standards, is considered a harmful factor.

The study of energy efficiency using lateral natural lighting was carried out both in Ukraine and abroad. In Ukraine, this issue was investigated by: Pidhornyi O.L. and Serhiichuk O.V. [2], Martynov V.L. [3], Filonenko O.I. [4, 5] and others. Abroad - Samoilov S.Y. and Solovev A.K. [6], Arasteh D.K. [7-9], Hart R. [8], Goudey H. [8, 9], Muhaisen A.S. [10], Klevets K. [11], Kolesnyk Y.A. [12], Zekraoui D. [13], Bülow-Hübe H. [14], Melendo J.M.A. [15], Dipa S. [16] and others.

${ }^{*}$ Corresponding author. Email address: vitaliy.burmaka@ gmail.com

This paper should be cited as: V. Burmaka, M. Tarasenko, K. Kozak, N. Sabat, V. Khomyshyn, V. Yuskiv. Conditions for ensuring energy-saving use of translucent structures of exterior wall envelope. Energy Engineering and Control Systems, 2020, Vol. 6, No. 2, pp. 71 - 80. https://doi.org/10.23939/jeecs2020.02.071 


\section{Formulation of the problem}

Determination of those parameters of TSEWE at which there will be a decrease in the total electricity consumption of the office room. From a practical point of view, the result will determine the necessary TSEWE area, CRPSR and thermal resistance, at which the savings from reducing the duration of the artificial lighting use will be greater than the cost of electricity to compensate for heat losses and revenues through TSEWE in a year.

\section{Analysis of recent research and publications}

The issue of energy-efficient buildings TSEWE rational orientation is considered in [3], [10], [17]. However, the authors did not take into account the heat input from solar radiation during the heating and cooling periods. Only one value of thermal resistance was taken into account; it does not allow us to state the uniqueness of the results for other values. Accordingly, the influence of solar radiation, which penetrates into the room, on the energy efficiency of buildings has not been established. The issue of heat input from solar radiation through the TSEWE of the southern facade in the winter and summer periods of the year, with the use and absence of sunscreens, were considered in [11]. However, the article does not address the influence of orientation and the coefficient of relative penetration of solar radiation (CRPSR) through TSEWE glazing on the amount of heat input into the building. In research [12] the analysis of the influence of the TSEWE thermal characteristics on the state of the indoor microclimate in the heating period is carried out. The authors determined the influence of the TSEWE integral thermal resistance on the amount of heat loss in the heating period, but did not focus on the seasons and TSEWE orientation. In [13] the issues of the influence of the TSEWE orientation and glazing area on heat loss and heat supply to office room with certain values of the thermal resistance of the exterior wall envelope (EWE) are considered. But the heat input from solar radiation during the heating period is not taken into account. The influence of the TSEWE orientation and size on the consumption of energy efficiency for heating and cooling the room was studied in [14], [15], [16]. The effect of thermal resistance and CRPSR in the room was not taken into account.

In [18] the dependence of the economically feasible resistance to heat transfer of the EWE of civil buildings was established for various regions of Ukraine on the number of degree-days of the heating period and an analytical description of the calculation results was presented. Obtained results make it possible to improve approaches to standardizing the required resistance of EWE thermal resistance taking into account the cost of heat energy and climatic characteristics of the area where the construction site is located.

According to [19], the use of daylight makes it possible to save up to $2 / 3$ of electric energy by reducing the expenses of artificial lighting. The data was obtained on a room layout reduced 50 -fold with specific dimensions. For rooms with other sizes, the results obtained cannot be applied.

In [20] a study of heat losses through the TSEWE and the energy consumption for heat removal, which enters through it, was conducted. However, the determination of the optimal TSEWE area, from the point of view of daylighting, for office rooms, was ignored. In research [21], the optimal value of the window to floor ratio (WFR) was studied for several rooms of various shapes and sizes. The disadvantage of the obtained results is that for rooms of different sizes the optimal WFR value turned out to be different, that is, the results obtained are valid only for those rooms that were considered in the study.

Solar energy gains and space-heating energy supply analyses for solid-wall dwelling retrofitted with the experimentally achievable $U$-value of novel triple vacuum glazing was studied in [22]. The space-heating annual cost of single glazed dwellings was minimized to $15.31 \%(\approx \mathrm{USD} 90.7)$ with the retrofit of triple-vacuum glazing. An influence of total heat-loss through the fabric of solid-wall dwelling was analyzed with steady-state calculations which indicate a fall of $10.23 \%$ with triple vacuum glazing compared to single glazing.

In the articles [23-27], a study was made to improve the methodology of the daylighting design in buildings. In [23], the daylight distribution in the premises of lecture halls was considered. In [25] and [26], the daylight calculating methods are analyzed and improved. As a result, a comprehensive method for calculating the illumination of buildings with a clear and cloudy sky was obtained [27]. However, these studies were aimed only at increasing the efficiency of daylighting without taking into account heat loss and heat gain through the TSEWE. In [24], experimental studies of the thermal properties of TSEWE were carried out, but the savings from the use of daylighting were not taken into account.

An analysis of the trend in lighting energy efficiency of the office rooms' assessments shows that in developed countries, electrical lighting expenses range from 5 to $15 \%$. While in developing countries they can reach up to $86 \%$ 
[28], [29]. Building lighting accounts for more than $40 \%$ of energy consumption in the European Union [30]. The cost of artificial and daylighting depends on which lamps are used. In [28] it was found that the most energy-efficient are fluorescent and LED lightings, and light wells or optical fibers - at the moment, it is an economically impractical option.

The authors of [31] calculated the light energy unit cost produced by a light source of average duration of luminescence $(\mathrm{UAH} \times \mathrm{W} /(\mathrm{Mlm} \times \mathrm{h})$ ) generated by incandescent, compact fluorescent lamps and LED light sources (LS). In [32] the whole gamut of existing LS is considered in more detail. For each type of LS, lamps with minimum and maximum nominal light output were selected. The energy parameters associated with the overheating of the room during the summer period and overcooling in winter were not considered.

This indicates that studies to determine the effect of thermal resistance, CRPSR and TSEWE glazing area on the flow rate to compensate for heat loss during the heating period and its removal during the cooling period are relevant.

\section{Results of the research}

The dependence of heat loss on the TSEWE thermal resistance value was determined according to the procedure presented in [33]. The rooms parameters of which correspond to the requirements of the current regulatory documents of Ukraine (DBN V.2.5-28-2006, DSTU B V.2.6-23:2009 and DBN V.2.6-31:2016) were analyzed.

A split system with artificial ventilation was chosen for room heating and cooling. The indoor workplace temperature of the heating system, following [42], is $20^{\circ} \mathrm{C}$. The indoor workplace temperature of the cooling system is $26^{\circ} \mathrm{C}$. All calculations were carried out for the Ternopil city $\left(49^{\circ} 34^{\prime} \mathrm{N}, 25^{\circ} 36^{\prime} \mathrm{E}\right)$.

Currently, a large number of free, high-precision programs for daylighting calculating have been developed, the reliability of which is verified by real measurements in [36], [37]. Therefore, the calculation of the daylight autonomy (DA) was carried out in the Relux program. The calculation was carried out based on data on the room location and the $D F$ value at the reference point (RP) on the working surface (WS).

Determination of heat loss through TSEWE with different thermal resistance was carried out according to the methods given in SNiP II-4-79 and DSTU-N B A.2.2-5.2007. In the calculations, buildings were considered whose parameters correspond to the requirements of the current regulatory documents of Ukraine (DSTU-N B B.2.6-83: 2009, DBN B.2.5-28: 2018, DSTU B B.2.6-23: 2009, DBN B.2.6-31: 2016, DSTU B EN 15251, SNiP II-33- 75, DSTU-N B A.2.2-5-2007 and DSTU-N B V.1.1-27 2010). In accordance with them, the values of the calculated values of the building envelope and the environment were chosen. All calculations were carried out for the Ternopil city.

The electricity amount that was spent or saved by changing the TSEWE properties is determined by the equation (1).

$$
W_{\mathrm{TSEWE}}=W_{\mathrm{AL}}-\omega,(\mathrm{kW} \times \mathrm{h}) / \text { year, }
$$

where $W_{\mathrm{AL}}$ is electricity saved on artificial lighting by the use of daylight, $(\mathrm{kW} \times \mathrm{h}) / \mathrm{m}^{2} ; \omega$ is the electricity that the air conditioner consumes to compensate the heat loss and heat gain through the TSEWE, $(\mathrm{kW} \times \mathrm{h}) /$ year.

The energy saved through the use of daylighting is determined by the equation (2)

$$
W_{\mathrm{AL}}=\left(S_{\mathrm{R}} \cdot p_{\mathrm{AL}} \cdot D A_{300}\right),(\mathrm{kW} \times \mathrm{h}) / \text { year, }
$$

where $S_{\mathrm{R}}$ is room's floor area, $\mathrm{m}^{2} ; p_{\mathrm{AL}}$ is specific power of artificial lighting, $(\mathrm{kW} \times \mathrm{h}) / \mathrm{m}^{2} ; D A_{300}$ is daylight autonomy (at illumination of $300 \mathrm{~lx}$ ), h/year.

$D A_{300}$ can be defined in specialized Relux software for any location. In accordance with [36], for arbitrary sizes of the room and the TSEWE area, in Ternopil city, $D A_{300}$ determined by equation (3) with a standard deviation of 82.6 and a coefficient of determination of 0.979 .

$$
D A_{300}=-0,227 \cdot I_{\mathrm{GL} . \mathrm{R}}^{2}+45,854 \cdot I_{\mathrm{GL} . \mathrm{R}}-420,953, \mathrm{~h} / \text { year, }
$$

where $I_{\mathrm{GL} . \mathrm{R}}$ is composite room glazing index (CRGI) [37], \%. 
In accordance with [36], [37] CRGI determined by the equation (4)

$$
I_{\mathrm{GL} . \mathrm{R}}=1.1 \cdot 0.8 / \varepsilon_{\mathrm{GL}} \cdot\left(-2.148 \cdot D F^{2}+27.087 \cdot D F+0.487\right), \%,
$$

where 1.1 is safety factor [37]; $\varepsilon_{\mathrm{GL}}$ is coefficient of relative penetration of solar radiation through TSEWE glazing, rel. un.

The energy consumption for the air conditioner to compensate for heat loss and heat gain through the TSEWE, according to [33], is determinate by the equation (5).

$$
\omega=\left(\omega_{\mathrm{H}}-Q_{\mathrm{H}}\right) / C O P+Q_{\mathrm{C}}^{\mathrm{MAX}} / E E R,(\mathrm{~kW} \times \mathrm{h}) / \text { year},
$$

where $\omega_{\mathrm{H}}$ is thermal energy losses in the heating period, $(\mathrm{kW} \times \mathrm{h}) /$ year [38]; $Q_{\mathrm{H}}$ is solar radiation gaining through the TSEWE during the heating period $(\mathrm{kW} \times \mathrm{h}) /$ year [39]; $C O P$ is coefficient of performance $(\mathrm{kW} / \mathrm{kW}) ; Q_{\mathrm{C}}{ }^{\mathrm{MAX}}$ is the highest value of heat solar radiation gaining into the working space through the TSEWE glazing during the cooling period $(\mathrm{kW} \times \mathrm{h}) / y e a r[38]$; EER is energy efficiency ratio $(\mathrm{kW} / \mathrm{kW})$.

The loss of thermal energy through TSEWE $\left(\omega_{\mathrm{H}}\right)$, with the option of standby heating during off-hours was defined by [38] as the difference between losses through the TSEWE and the same area of the EWE (6).

$$
\omega_{\mathrm{H}}=\left(\begin{array}{l}
10^{-3} \cdot 1.1 \cdot(1.3+\eta) \cdot\left(1 / R_{\mathrm{TSEWE}}-1 / R_{\mathrm{E}}\right) \cdot z_{\mathrm{HP}} \cdot S_{\mathrm{TSEWE}} \times \\
\times\left[\left(t-t_{\mathrm{AV} . \text { OUTD. }}\right) \cdot T+\left(t_{\mathrm{ST} .}-t_{\mathrm{AV} . \text { outD. }}\right) \cdot(8760-T)\right]
\end{array}\right) / 365,(\mathrm{~kW} \times \mathrm{h}) / \text { year }
$$

where 1.1 is the coefficient, which takes into account heat losses in heating systems [38], rel. units; 1.3 is the coefficient which takes into account heat losses on heating the external air entering through TSEWE, according to [38], rel. units; $\eta$ is the coefficient which takes into account the additional heat losses through the EWE, it selected from the [40, add. 5, table 2] (table 1), rel. units; $R_{\mathrm{TSEWE}}$ is thermal resistance of TSEWE, $\left(\mathrm{m}^{2} \times{ }^{\circ} \mathrm{C}\right) / \mathrm{W} ; R_{\mathrm{E}}$ is economically attractive thermal resistance of the dumb part of EWE [41], $\left(\mathrm{m}^{2} \times{ }^{\circ} \mathrm{C}\right) / \mathrm{W} ; t_{\mathrm{AV} \text {.outD }}$ is average outdoor temperature for the heating period [42], ${ }^{\circ} \mathrm{C} ; t$ is the estimated winter air temperature indoors during working hours [42], ${ }^{\circ} \mathrm{C} ; T$ is annual working hours, taken as 2150 hours when working in one shift, 4300 hours when working in two shifts, $6500 \mathrm{~h}$ when working in three shifts, h/year; $S_{\text {TSEWE }}$ is TSEWE area in ceiling or EWE, $\mathrm{m}^{2} ; z_{\mathrm{HP}}$ is the duration of the heating period for residential premises [43], days; $t_{\mathrm{ST}}$ is the temperature inside the room, in standby heating mode $[46],{ }^{\circ} \mathrm{C}$.

From [44] and [45] it is known that the relative area of glazing depends on the TSEWE proportions and thermal resistance depends on the size of its profile, glazing and foam filling.

Table 1 Additional heat loss for vertical surface

\begin{tabular}{|l|c|c|c|}
\hline Orientation & $\mathrm{S}$ & $\mathrm{N}, \mathrm{E}$ & $\mathrm{W}$ \\
\hline$\eta, \%$ & 0 & 10 & 5 \\
\hline
\end{tabular}

Beyond working hours during standby heating mode the air temperature inside the premises $\left(t_{\mathrm{ST}}\right)$ was assumed to be equal $5^{\circ} \mathrm{C}$ for industrial and $10-12^{\circ} \mathrm{C}$ for the all office rooms [46]. In this calculations the temperature inside the room, in standby heating mode was equal $12^{\circ} \mathrm{C}$.

According to [33], the equation for determining thermal energy losses in the heating period $\omega_{\mathrm{H}},(\mathrm{kW} \times \mathrm{h}) / \mathrm{year}$ through TSEWE for the Ternopil city, with the option of standby heating, out of work hours, becomes (7).

$$
\omega_{\mathrm{H}}=89,44 \cdot S_{\mathrm{TSEWE}} \cdot(1,3+\eta) \cdot\left(1 / R_{\mathrm{TSEWE}}-1 / R_{\mathrm{E}}\right),(\mathrm{kW} \times \mathrm{h}) / \text { year. }
$$

Due to the fact that heat losses through the TSEWE are directly proportional to its area, equation (8) can be used to calculate the TSEWE of different size. Since the dependence of heat loss through the TSEWE on orientation is characterized only by the coefficient of additional heat energy losses, the total losses will differ from them by the same value [33]. 
Solar radiation gaining through the TSEWE during the heating period $(\mathrm{kW} \times \mathrm{h}) / \mathrm{year}$, for the facades of the building oriented in four directions - South (S), North (T), West (W) and East (E), we determined, according to [39], by equation (8)

$$
Q_{\mathrm{H}}=\zeta_{\mathrm{TSEWE}} \cdot \varepsilon_{\mathrm{GL}} \cdot\left(S_{\mathrm{TSEWE} . \mathrm{S}} \cdot I_{\mathrm{S}}+S_{\mathrm{TSEWE} . \mathrm{N}} \cdot I_{\mathrm{N}}+S_{\mathrm{TSEWE} . \mathrm{W}} \cdot I_{\mathrm{W}}+S_{\text {TSEWE.E }} \cdot I_{\mathrm{E}}\right),(\mathrm{kW} \times \mathrm{h}) / \text { year, }
$$

where $\zeta_{\text {TSEWE }}$ is the coefficient that taking into account the shading of the TSEWE opaque elements [47, table 1], rel. units; $S_{\text {TSEWE.s }}, S_{\text {TSEWE.N }}, S_{\text {TSEwE.w }}, S_{\text {TSEWE..E }}$ are the TSEWE areas in the facades of the building, oriented to South, North, West and East, respectively, $\mathrm{m}^{2} ; I_{\mathrm{S}}, I_{\mathrm{N}}, I_{\mathrm{W}}, I_{\mathrm{E}}$ are the average values of solar radiation for the heating period, directed to a vertical surface in cloudy conditions, and oriented accordingly to South, North, West and East [39, table 2] $(\mathrm{kW} \times \mathrm{h}) / \mathrm{m}^{2}$.

The initial data for determining the receipt of solar radiation through the TSEWE for the heating period for the city of Ternopil are given in table 2.

Table 2 Data on the solar gaining radiation through the TSEWE for the heating period

\begin{tabular}{|l|c|c|c|c|}
\hline Quantity & $I_{\mathrm{S}},(\mathrm{kW} \times \mathrm{h}) / \mathrm{m}^{2}$ & $I_{\mathrm{N}},(\mathrm{kW} \times \mathrm{h}) / \mathrm{m}^{2}$ & $I_{\mathrm{W}},(\mathrm{kW} \times \mathrm{h}) / \mathrm{m}^{2}$ & $I_{\mathrm{E}},(\mathrm{kW} \times \mathrm{h}) / \mathrm{m}^{2}$ \\
\hline Value & 249.2 & 86.1 & 145.6 & 14.2 \\
\hline
\end{tabular}

In the equation (9), to take into account the TSEWE opaque elements, the coefficient $\zeta_{\text {TSEWE }}$ is using, which, in accordance with the number of chambers and the arrangement of double-glazed windows, indicates the share of the TSEWE area, through which solar radiation penetrates the room. That is, it indicates the TSEWE relative glazing area $\left(\zeta_{\mathrm{TSEWE}}=\bar{s}_{\mathrm{GL}}\right)$. Its disadvantage is that it does not take into account the TSEWE area, and according to [44], the TSEWE relative glazing area has different values for different TSEWE area and proportions. Therefore, to improve this calculation, it is proposed to replace the multiplication of $\zeta_{\text {TSEWE }}$ and the $S_{\text {TSEWE }}$ by the TSEWE glazing (9).

$$
S_{\mathrm{GL}}=\bar{s}_{\mathrm{GL}} \cdot S_{\mathrm{TSEWE}}, \mathrm{m}^{2},
$$

where $\bar{s}_{\mathrm{GL}}$ is relative area of TSEWE glazing, rel. un.

$$
Q_{\mathrm{H}}=\varepsilon_{\mathrm{GL}} \cdot\left(S_{\mathrm{GL} . \mathrm{S}} \cdot I_{\mathrm{S}}+S_{\mathrm{GL} . \mathrm{N}} \cdot I_{\mathrm{N}}+S_{\mathrm{GL} . \mathrm{W}} \cdot I_{\mathrm{W}}+S_{\mathrm{GL} . \mathrm{E}} \cdot I_{\mathrm{E}}\right),(\mathrm{kW} \times \mathrm{h}) / \text { year, }
$$

where $S_{\mathrm{GL} . \mathrm{S}}, S_{\mathrm{GL} . \mathrm{N}}, S_{\mathrm{GL} . \mathrm{w}}, S_{\mathrm{GL} . \mathrm{E}}$ are the glazing areas in the facades of the building, oriented to South, North, West and East, respectively, $\mathrm{m}^{2}$.

The highest value of heat solar radiation gaining into the working space during the cooling period is determined by the maximum value of total solar radiation incoming through the TSEWE glazing during the day and is calculated according to [38], by the equation (11).

$$
Q_{\mathrm{C}}^{\mathrm{MAX}}=\left(Q_{\mathrm{DIR} . \mathrm{R} . \mathrm{VII}}^{\mathrm{MAX}}+Q_{\mathrm{DIF} . \mathrm{M} . \mathrm{VII}}^{\mathrm{MAX}}\right) \cdot \varepsilon_{\mathrm{TSEWE}} \cdot \tau_{2} \cdot \tau_{3} \cdot \tau_{4} \cdot \bar{s} \cdot S_{\mathrm{TSEWE}} \cdot T_{\mathrm{C}} \cdot 10^{-3},(\mathrm{~kW} \times \mathrm{h}) / \text { year }
$$

where $Q_{\text {DIR.R.VII }}^{\mathrm{MAX}}$ is the highest value of direct solar radiation in July at the time of a cloudless sky on a vertical surface by a certain orientation [43], W/m²; $Q_{\text {DIF.R.VII }}^{\mathrm{MAX}}$ is the highest value of diffuse solar radiation in July in the cloudless sky on the vertical surface of a certain orientation [43], W/m $\mathrm{m}^{2} ; \tau_{2}$ is the coefficient that takes into account the light loss of the translucent hole bindings [48], rel. un.; $\tau_{3}$ is the coefficient that takes into account the decreasing of heat gains due to a glass pollution [40, add. 12], rel. unit; $\tau_{4}$ is the coefficient of heat transmission of shading devices [48], rel. unit; $T_{\mathrm{C}}$ is duration of the cooling system work, is determined from [49], $\mathrm{h} /$ year.

The highest value of heat solar radiation gaining into the working space through the TSEWE glazing, according to [33], for Ternopil city, depending on the orientation is determined by the equations (12), (13) and (14) 
76 Vitalii Burmaka, Mykola Tarasenko, Kateryna Kozak, Nataliia Sabat, Viktor Khomyshyn, Volodymyr Yuskiv

- South orientation:

$$
Q_{\mathrm{C}}^{\mathrm{MAX}}=145.62 \cdot \bar{s}_{\mathrm{GL}} \cdot S_{\mathrm{TSEWE}, \mathrm{S}} \cdot \varepsilon_{\mathrm{GL}},(\mathrm{kW} \times \mathrm{h}) / \text { year; }
$$

- North orientation:

$$
Q_{\mathrm{C}}^{\mathrm{MAX}}=35.69 \cdot \bar{s}_{\mathrm{GL}} \cdot S_{\mathrm{TSEWE} . \mathrm{N}} \cdot \varepsilon_{\mathrm{GL}},(\mathrm{kW} \times \mathrm{h}) / \text { year; }
$$

- West and East orientations:

$$
Q_{\mathrm{C}}^{\mathrm{MAX}}=187.88 \cdot \bar{s}_{\mathrm{GL}} \cdot S_{\mathrm{TSEWE} .(\mathrm{W} / \mathrm{E})} \cdot \varepsilon_{\mathrm{GL}},(\mathrm{kW} \times \mathrm{h}) / \text { year. }
$$

According to [33], the average $C O P$ value for modern ducted air conditioners is 3.41 , and the EER is 2.73 . Thermal resistance for the first temperature zone of Ukraine is $R_{\mathrm{E}}=3.3\left(\mathrm{~m}^{2} \times{ }^{\circ} \mathrm{C}\right) / \mathrm{W}$. Equations for determining the energy savings by using of the TSEWE, for the Ternopil city, take the form (15), (16), (17) and (18).

- South orientation:

$$
W_{\mathrm{TSEWE}}=S_{\mathrm{R}} \cdot p_{\mathrm{AL}} \cdot D A_{300}-S_{\mathrm{TSEWE} . \mathrm{S}} \cdot\left(\left(34.097 / R_{\mathrm{TSEWE}}-10.333\right)-19.74 \cdot \overline{\mathrm{S}}_{\mathrm{GL}} \cdot \varepsilon_{\mathrm{GL}}\right), \quad(\mathrm{kW} \times \mathrm{h}) / \text { year} ;
$$

- North orientation:

$$
W_{\mathrm{TSEWE}}=S_{\mathrm{R}} \cdot p_{\mathrm{AL}} \cdot D A_{300}-S_{\mathrm{TSEWE.N}} \cdot\left(\left(36.720 / R_{\mathrm{TSEWE}}-11.127\right)-12.18 \cdot \bar{s}_{\mathrm{GL}} \cdot \varepsilon_{\mathrm{GL}}\right),(\mathrm{kW} \times \mathrm{h}) / \text { year; }
$$

- West orientation:

$$
W_{\mathrm{TSEWE}}=S_{\mathrm{R}} \cdot p_{\mathrm{AL}} \cdot D A_{300}-S_{\text {TSEWE. }} \cdot\left(\left(35.409 / R_{\mathrm{TSEWE}}-10.730\right)+26.12 \cdot \overline{\mathrm{GL}}_{\mathrm{GL}} \cdot \varepsilon_{\mathrm{GL}}\right), \quad(\mathrm{kW} \times \mathrm{h}) / \text { year; }
$$

- East orientation:

$$
W_{\mathrm{TSEWE}}=S_{\mathrm{R}} \cdot p_{\mathrm{AL}} \cdot D A_{300}-S_{\mathrm{TSEWE} . \mathrm{E}} \cdot\left(\left(36.720 / R_{\mathrm{TSEWE}}-11.127\right)+27.12 \cdot \bar{s}_{\mathrm{GL}} \cdot \varepsilon_{\mathrm{GL}}\right), \quad(\mathrm{kW} \times \mathrm{h}) / \text { year. }
$$

As a result of the equations (15), (16), (17) and (18) analysis, it can be concluded that for the southern (15) and northern (16) orientations, an increase of the CRPSR leads to an increase in energy savings (negative coefficient), while for the western (17) and eastern (18) - to a decrease. However, do not forget that an increase in CRPSR leads to an increase in the amount of daylight entering the room, reducing the energy consumption of the artificial lighting system.

Based on the equations (15), (16), (17) and (18), we obtain inequalities (19), (20), (21) and (22) to determine the TSEWE parameters at which it will have a positive effect on the total energy balance of the room for Ternopil city:

- South orientation:

$$
S_{\mathrm{R}} \cdot p_{\mathrm{AL}} \cdot D A_{300}>S_{\text {TSEWE. }} \cdot\left(\left(34.097 / R_{\mathrm{TSEWE}}-10.333\right)-19.74 \cdot \bar{s}_{\mathrm{GL}} \cdot \varepsilon_{\mathrm{GL}}\right),(\mathrm{kW} \times \mathrm{h}) / \text { year; }
$$

- North orientation:

$$
S_{\mathrm{R}} \cdot p_{\mathrm{AL}} \cdot D A_{300}>S_{\text {TSEWE.N }} \cdot\left(\left(36.720 / R_{\mathrm{TSEWE}}-11.127\right)-12.18 \cdot \bar{s}_{\mathrm{GL}} \cdot \varepsilon_{\mathrm{GL}}\right),(\mathrm{kW} \times \mathrm{h}) / \text { year } / \text { year; }
$$

- West orientation:

$$
S_{\mathrm{R}} \cdot p_{\mathrm{AL}} \cdot D A_{300}>S_{\mathrm{TSEWE} . \mathrm{W}} \cdot\left(\left(35.409 / R_{\mathrm{TSEWE}}-10.730\right)+26.12 \cdot \bar{s}_{\mathrm{GL}} \cdot \varepsilon_{\mathrm{GL}}\right),(\mathrm{kW} \times \mathrm{h}) / \text { year } / \text { year; }
$$


- East orientation:

$$
S_{\mathrm{R}} \cdot p_{\mathrm{AL}} \cdot D A_{300}>S_{\mathrm{TSEWE} . \mathrm{E}} \cdot\left(\left(36.720 / R_{\mathrm{TSEWE}}-11.127\right)+27.12 \cdot \bar{s}_{\mathrm{GL}} \cdot \varepsilon_{\mathrm{GL}}\right),(\mathrm{kW} \times \mathrm{h}) / \text { year. }
$$

For example, we calculate at which area of the TSEWE area, with Veka Softline 82 profile, with thermal resistance $1\left(\mathrm{~m}^{2} \times{ }^{\circ} \mathrm{C}\right) / \mathrm{W}$ and triple-glazed window 4 Solar-16Ar-4-12Ar-4i, with thermal resistance $1.14\left(\mathrm{~m}^{2} \times{ }^{\circ} \mathrm{C}\right) / \mathrm{W}$ and CRPSR equal 0.68 rel. un., which is installed in a room with dimensions $(\mathrm{w} \times \mathrm{l} \times \mathrm{h}) 6 \times 4 \times 3 \mathrm{~m}$ maximum energy efficiency will be achieved. For this, using equations (4), we determine the CRGI value for the $D F$ values, according to [37] from 0.6 to 2.2 , by equation (3) define $D A_{300}$ for the obtained values of the CRGI, and according to the algorithm [36] we get the TSEWE area, which will provide the corresponding $D A_{300}$ value.

Based on the obtained CRGI value, by [37] it is possible to determine the minimum TSEWE glazing area at which $D F$ value prescribed by regulations is provided at the reference point on the working surface.

Engineering calculation of the actual reduced TSEWE thermal resistance might be performed with sufficient accuracy based on European regulatory documents (DIN EN ISO 10077 «Thermal performance of windows, doors and shutters - Calculation of thermal transmittance» and DIN V 4108 «Thermal insulation and energy economy in buildings».

For most cases, to determine the integral thermal resistance of rectangular TSEWE, mounted in the slot of the main carrier of an opaque EWE, by [41], a simplified equation can be used at the engineering design stage (23).

$$
R_{\mathrm{TSEWE}}=\left(S_{\mathrm{GL}}+\sum_{i=1}^{n} S_{i}\right) /\left(S_{\mathrm{GL}} / R_{\sum_{\mathrm{GL}}}+\sum_{i=1}^{n} S_{i} / R_{\sum_{i}}+\sum_{j=1}^{m} k_{j} \cdot L_{j}\right),\left(\mathrm{m}^{2} \cdot{ }^{\circ} \mathrm{C}\right) / \mathrm{W} .
$$

As a result of the calculations, for the given parameters, the value of the TSEWE area, CRGI, $D A_{300}$ and $R_{\mathrm{TSEWE}}$ was obtained, which are given in table 3.

\begin{tabular}{|c|c|c|c|c|c|c|c|c|c|c|c|}
\hline$D F, \%$ & 0.6 & 0.8 & 1 & 1.2 & 1.4 & 1.6 & 1.7 & 1.8 & 1.9 & 2 & 2.2 \\
\hline$I_{\mathrm{GL} . \mathrm{R}}, \%$ & 20.66 & 26.89 & 32.90 & 38.69 & 44.26 & 49.60 & 52.19 & 54.72 & 57.20 & 59.62 & 64.29 \\
\hline$D A_{300}, \mathrm{~h} /$ year & 429.5638 & 648.0649 & 842.0675 & 1013.392 & 1163.791 & 1294.951 & 1353.824 & 1408.489 & 1459.137 & 1505.957 & 1588.838 \\
\hline$S_{\mathrm{GL}}, \mathrm{m}^{2}$ & 2.53 & 3.29 & 4.02 & 4.73 & 5.41 & 6.07 & 6.69 & 6.99 & 7.29 & 7.86 & 9.88 \\
\hline$S_{\mathrm{PROF}}, \mathrm{m}^{2}$ & 0.49 & 0.55 & 0.61 & 0.66 & 0.70 & 0.74 & 0.78 & 0.79 & 0.81 & 0.84 & 0.94 \\
\hline$S_{\mathrm{F} . \mathrm{F}}, \mathrm{m}^{2}$ & 0.08 & 0.10 & 0.12 & 0.13 & 0.15 & 0.17 & 0.18 & 0.19 & 0.20 & 0.21 & 0.26 \\
\hline$S_{\text {TSEWE }}, \mathrm{m}^{2}$ & 3.10 & 3.94 & 4.75 & 5.52 & 6.26 & 6.97 & 7.65 & 7.98 & 8.30 & 8.91 & 11.08 \\
\hline$R_{\mathrm{TSEWE}}$ & 0.82 & 0.83 & 0.85 & 0.86 & 0.86 & 0.87 & 0.87 & 0.88 & 0.88 & 0.88 & 0.89 \\
\hline
\end{tabular}

Table 3 the value of the TSEWE area, CRGI, $D A_{300}$ and $R_{\text {TSEWE }}$ for TSEWE with the set parameters

Let's consider the impact of TSEWE on the energy balance of the room for its southern orientation (table 4)

Table 4 Energy savings when using TSEWE $\left(W_{\text {TSEWE }}\right)$ for different values of specific electricity consumption by artificial lighting

\begin{tabular}{|c|c|c|c|c|c|c|c|c|c|c|c|}
\hline \multirow{2}{*}{$p_{\mathrm{AL}}, \mathrm{kW} / \mathrm{m}^{2}$} & \multicolumn{11}{|c|}{$D F, \%$} \\
\hline & 0.6 & 0.8 & 1.0 & 1.2 & 1.4 & 1.6 & 1.7 & 1.8 & 1.9 & 2.0 & 2.2 \\
\hline 0.005 & 24.018 & 43.714 & 60.836 & 75.551 & 88.040 & 98.486 & 100.510 & 104.641 & 108.350 & 109.408 & 103.393 \\
\hline 0.01 & 75.565 & 121.482 & 161.884 & 197.158 & 227.695 & 253.880 & 262.969 & 273.660 & 283.447 & 290.123 & 294.053 \\
\hline 0.015 & 127.113 & 199.250 & 262.932 & 318.765 & 367.350 & 409.274 & 425.428 & 442.678 & 458.543 & 470.838 & 484.714 \\
\hline 0.02 & 178.661 & 277.017 & 363.980 & 440.372 & 507.005 & 564.668 & 587.887 & 611.697 & 633.640 & 651.552 & 675.374 \\
\hline
\end{tabular}
and $D F$ value in the RP for a room with dimensions of $6 \times 4 \times 3 \mathrm{~m}, \mathrm{kWh} /$ year

As can be seen from the table 4, energy savings for rooms with TSEWE for the Ternopil city occur even with a specific power of the artificial lighting system of $0.005 \mathrm{~kW} / \mathrm{m}^{2}$ and a $D F$ value of $0.6 \%$. As a result, it can conclude that the establishment of modern TSEWE leads to a decrease in the total electricity consumption to ensure climatic conditions in the office rooms prescribed by regulations.

\section{Conclusion}

The article focuses on determining the TSEWE properties with which its use will have a positive effect on the room`s total energy balance. From a practical point of view, the result allows one to determine the required area of 
TSEWE, CRPSR and thermal resistance, at which energy savings are achieved, that is decrease in the artificial lighting using duration and heat in the heating period from TSEWE.

As a result, analytical equations were obtained to determine the energy saving for artificial lighting on the $D F$ value and its specific consumption by the artificial lighting system. The obtained equations make it possible to determine those TSEWE properties at which the energy savings for artificial lighting and heat gain during the heating period will be greater than the heat loss compensation and removal of excess heat.

It is established that the use of modern TSEWE in the office rooms in the Ternopil city can reduce the total electricity consumption at specific electrical power consumption by the artificial lighting system of $0.005 \mathrm{~kW} / \mathrm{m}^{2}$ and the $D F$ value of $0.6 \%$. When the $D F$ value increases so do the total electricity savings.

\section{References}

[1] Tarasenko M., Kozak K., Burmaka V. (2015). Dynamic of parameters of high-pressure discharge lamp at building-up and dimming. Lighting Engineering \& Power Engineering, 3-4, 15-21. (in Ukrainian).

[2] Pidhornyi O.L., Ploskyi V.O., Serhiichuk O.V. (2010). Actual problems of geometric modeling in the tasks of energy conservation in construction. Ventyliatsiia, Osvitlennia ta Teplohazopostachannia, 14, 25-31. (in Ukrainian).

[3] Martynov V.L. (2013). Optimization of orientation of energy-efficient buildings in compliance with lighting and insolation standards. Visnyk Kremenchutskoho natsionalnoho universytetu imeni Mykhaila Ostrohradskoho, 5, 84-89. (in Ukrainian).

[4] Filonenko O.I. (2013). Effect of breathability of a structure on its heat-shielding properties. Zbirnyk naukovykh prats' [National University «Yuri Kondratyuk Poltava Polytechnic»]. Ser.: Industry engineering, construction, 4(1), 261-265. (in Ukrainian).

[5] Filonenko O.I., Velboi M.A. (2013). Analysis of energy efficiency of wall structures depending on their architectural and structural features. Zbirnyk naukovykh prats' [National University «Yuri Kondratyuk Poltava Polytechnic»]. Ser.: Industry engineering, construction, 4(2), 233239. (in Ukrainian).

[6] Samoilov S.Y., Solovev A.K. (2000). Designing of the window openings in offices and saving energy. Svetotekhnyka, 1, 23-25. (in Russian).

[7] Arasteh D.K., Kohler C., Griffith B. (2009). Modeling windows in energy plus with simple performance indices. Department of Energy R\&D, USA.

[8] Hart R., Goudey H., Arasteh D.K., Curcija D.C. (2012). Thermal performance impacts of center-of-glass deflections in installed insulating glazing units. Energy and Buildings, 54, 453-460. https://doi.org/10.1016/j.enbuild.2012.06.026

[9] Gustavsen A., Grynning S., Arasteh D.K., Jelle B.P., Goudey H. (2011). Window sizes required for the energy efficiency of a building against window sizes required for view. Energy and Buildings, 43(10), 2583-294. https://doi.org/10.1016/j.enbuild.2011.05.010

[10] Muhaisen A.S., Dabboor H.R. (2015). Studying the impact of orientation, size, and glass material of windows on heating and cooling energy demand of the Gaza strip buildings. Journal of Architecture and Planning, 27, 1-15.

[11] Klevets K. (2013). Influence of heat income through of the south facade windows for the creation of comfort conditioning. Applied geometry and graphics, 91, 196-200. (in Ukrainian).

[12] Kolesnyk Y.A., Petrenko V.O., Vetvytskyi Y.L., Vetvytskaia D.A. (2016). Analysis of influence thermal performance of windows on the state room climate during the heating period. Construction, Materials Science, Mechanical Engineering, 92, 67-72. (in Russian).

[13] Zekraoui D., Zemmouri N. (2017). The impact of window configuration on the overall building energy consumption under specific climate. Energy Procedia, 115, 162-172. https://doi.org/10.1016/j.egypro.2017.05.016

[14] Bülow-Hübe H. The effect of glazing type and size on annual heating and cooling demand for Swedish offices. Proc. of Renewable Energy Technologies in Cold Climates '98. Montréal, Québec, Canada, 1998, pp. 188-193.

[15] Melendo J.M.A., la Roche P. Effects of window size in daylighting and energy performance in buildings. American Solar Energy Society SOLAR2008, Including Proc of 37th ASES Annual Conf, 33rd National Passive Solar Conf, 3rd Renewable Energy Policy and Marketing Conf: Catch the Clean Energy Wave2008, 2008, pp. 4345-4351.

[16] Dipa S., Sazdik A., Shahriar A.T.M, Mithun N.H. (2017). North-south vs east-west: the impact of orientation in daylighting design for educational buildings in Bangladesh. Architecture Research, 7(4),184-189. https://doi.org/10.5923/j.arch.20170704.06

[17] Eljojo A. (2017). Effect of windows size, position and orientation on the amount of energy needed for winter heating and summer cooling. Journal of Engineering Research and Technology, 1(1), 1-8. http://dx.doi.org/10.13140/RG.2.2.32424.47361

[18] Kariuk A.M. Koshlatyi O.B. (2015). Economically viable heat resistance of exterior walls of civil buildings for different regions of Ukraine. Novì tehnologï v budìvnictvì, 29, 35-39.

[19] Firas M.S. (2014). Daylighting: an alternative approach to lighting buildings. Journal of American Science, 10(4), 1-5.

[20] Noureddine Z., Djamel Z. The impact of window configuration on the overall building energy consumption under specific climate conditions. International conference - alternative and renewable energy quest, areq 2017, 1-3 February, No. 115, $2017,162-172$. http://doi.org/10.1016/j.egypro.2017.05.016

[21] Nedhal A., Syed F.S.F., Adel A. (2016). Relationship between window-to-floor area ratio and single-point daylight factor in varied residential rooms in Malaysia. Indian. Journal of Science and Technology, 33(9), 1-8. http://doi.org/10.17485/ijst/2016/v9i33/86216 
[22] Memon S., Eames P.C. (2017). Solar energy gain and space-heating energy supply analyses for solid-wall dwelling retrofitted with the experimentally achievable u-value of novel triple vacuum glazing. Journal of Daylighting, 4, 15-25. http://dx.doi.org/10.15627/jd.2017.2

[23] Galinska T.A., Krepka T.S. (2011). Experimental researches of distribution of natural illumination in apartments of lecture audiences of PoltNTU "P" corps which realizes through lateral lightopening in protection of building. Industrial Machine Building, Civil Engineering, 30(2), 241-251.

[24] Galinska T.A., Nosach B.L., Leshchenko M.V., Likhtei V.V. (2013). Experimental studies of the thermal properties of translucent enclosing building envelope. Construction, materials science, mechanical engineering, 68, 104-108.

[25] Galinska T.A. (2013). Improvement of techniques designing of the daylight in premises of the building. Resource-saving materials, structures, buildings and structures, 25, 528-541.

[26] Galinska T.A. (2006). Calculation of daylighting in buildings, illuminated through zenith rectangular lanterns in plan with a clear and cloudy sky. Scientific and technical collection is the «Communal economy of cities», 76, 151-158.

[27] Galinska T.A. A comprehensive method for solving the lighting of buildings under clear and cloudy skies. National University «Yuri Kondratyuk Poltava Polytechnic». Poltava, 2011, 24.

[28] Chernenko P.O., Martyniuk O.V. (2012). Enhancing the effectiveness of short-term forecasting of electric load of united power system. Tekhnichna Elektrodynamika, 1, 63-70. (in Ukrainian).

[29] eia. U. S. Energy Information Administration. Available at: https://www.eia.gov/tools/faqs/faq.php?id=99\&t=3

[30] Ajzenberg Ju.B., Varfolomeev L.P. (2011). How to increase lighting energy efficiency. Spec. issue AVOK, 3, 52-56. (in Russian).

[31] Kozhushko G., Basova Yu., Huba L. (2016). Comparison of the dynamics of light and color characteristics of compact fluorescent and led lamps in process of service life. Technology audit and production reserves, 30(4), 63-69. (in Ukrainian). http://doi.org/10.15587/23128372.2016 .74678

[32] Tarasenko M., Kozak K. (2013). Comprehensive approach to determine the energy efficiency of light sourse. Lighting Engineering \& Power Engineering, 33(1), 27-33. (in Ukrainian).

[33] Burmaka V., Tarasenko M., Kozak K., Khomyshyn V. (2019). Impact of the translucent structures of exterior wall envelope orientation on the energy balance of the premises. Scientific Journal of TNTU (Tern.), 94(2), 111-122. https://doi.org/10.33108/visnyk_tntu2019.02.111

[34] Byrne P. (2014). Comparison Study of Four Popular Lighting Simulation Software Programs. Brunel University.

[35] Gábrová L., Hlásková M., Vajkay F. (2016). Comparative Evaluation of Daylighting Simulation Programs. Applied Mechanics and Materials, 824, 732-739. https://doi.org/10.4028/www.scientific.net/amm.824.732

[36] Burmaka V., Tarasenko M., Kozak K., Omeiza L.A., Sabat N. (2020). Efficiency using of daylight in office rooms. Journal of Daylighting, 7(2), 154-166. https://dx.doi.org/10.15627/jd.2020.15

[37] Burmaka V., Tarasenko M., Kozak K., Khomyshyn V. (2018). Definition of a composite index of glazing rooms. Eastern-European Journal of Enterprise Technologies, 94(4(10)), 22-28. http://dx.doi.org/10.15587/1729-4061.2018.141018

[38] A guide to the calculation and design of natural, artificial and combined lighting (to SNiP II-4-79). M.: Strojizdat, 1980, 156 p.

[39] Guidelines for the development and compilation of an energy passport of buildings for new construction and reconstruction: DSTU-N B A.2.2-5.2007. K.: Ministry of Regional Development and Construction of Ukraine, 2008.

[40] Building regulations. Part II «Design standards. Chapter 33 «Heating, ventilation and air conditioning»: SNiP II-33-75. M.: Strojizdat, 1976, $109 \mathrm{p}$.

[41] Thermal insulation of buildings: DBN V.2.6-31:2016. K.: Ministry of Regional Development of Ukraine, 2017,31 p.

[42] Estimated parameters of the microclimate of premises for the design and assessment of the energy characteristics of buildings in relation to air quality, thermal comfort, lighting and acoustics (EN 15251:2007, IDT): DSTU B EN 15251. K.: Ministry of Regional Development, Construction and Housing of Ukraine, 2008, 33 p.

[43] Construction climatology: DSTU-N B V.1.1-27 2010. K.: Ministry of Regional Development of Ukraine, 2011,123 p.

[44] Tarasenko M., Burmaka V., Kozak K. (2018). Dependences of relative and absolute glazed area from configuration and common areas of window embrasure. Scientific Journal of TNTU (Tern.), 89(1), 122-131. https://doi.org/10.33108/visnyk_tntu2018.01.122

[45] Tarasenko M., Burmaka V., Kozak K. "Relative area of glazing dependences from the overall area of the window embrasure". Materials 6th International Scientific Conference «Lighting and power engineering: history, problems and perspectives» (Tern., January 30 - February 02, 2018), 2018, pp. 99-100. (in Ukrainian).

[46] Engineering encyclopedia. URL: http://engineeringsystems.ru/d/dejurnoe-otoplenie.php.

[47] Guidelines for the development and compilation of an energy passport of buildings for new construction and reconstruction: DSTU-N B A.2.2-5.2007. K.: Ministry of Regional Development and Construction of Ukraine, 2008.

[48] Daylighting and artificial lighting: DBN V.2.5-282018. K.: Ministry of Regional Development of Ukraine, 2018,113 p.

[49] Liubarets O.P. (2018). Calculation parameters for cooling period in Ukraine. Heating, Ventilation and Air Conditioning in Buildings, 24, 1116. (in Ukrainian). 


\title{
Умови забезпечення енергоощадного використання світлопрозорих зовнішніх огороджувальних конструкцій
}

\author{
Віталій Бурмака $^{a}$, Микола Тарасенко ${ }^{a}$, Катерина Козак ${ }^{a}$, Наталія Сабат $^{b}$, \\ Віктор Хомишин ${ }^{a}$, Володимир Юськів ${ }^{a}$ \\ ${ }^{a}$ Тернопільський начіональний технічний університет імені Івана Пулюя, Тернопіль, 46001, Украйна \\ ${ }^{b}$ Івано-Франківський національний технічний університет нафти і газу, Івано-Франківськ, 76019, Украӥна
}

\section{Анотація}

Стаття присвячена визначенню впливу властивостей світлопрозорих зовнішніх огороджувальних конструкцій (СЗОК) на сумарний енергетичний баланс приміщення. Розглянуто вплив термічного опору та коефіцієнту відносного проникнення сонячної радіації (КВПРС) засклення СЗОК на величину витрати електроенергії в опалювальний та охолоджувальний періоди для компенсації втрат та надходжень теплової енергії відповідно. Визначено залежність витрат електроенергії на штучне освітлення від величини коефіцієнта природного освітлення в розрахунковій точці на робочій поверхні, КВПСР та від площі СЗОК для м. Тернопіль. Встановлено залежність між витратами електроенергії на опалення та охолодження приміщення канальними кондиціонерами від розмірів та властивостей СЗОК. Це дає можливість визначати ті значення термічного опору та КВПСР, при яких використання СЗОК дозволить зменшити сумарне споживання електроенергії офісним приміщенням. Отримано нерівності, які дозволяють визначати термічний опір, КВПСР та площу СЗОК при яких буде виникати економія електроенергії при дотриманні нормованих показників клімату приміщення. Незважаючи на те, що результати розрахунків представлені тільки для м. Тернопіль, розроблена методика дійсна для будь-якого регіону.

Ключові слова: СЗОК; коефіцієнт природного освітлення; зведений індекс засклення приміщення; енергоефективність природного освітлення. 